\title{
Samuel Beckett's Trilogy, Alain Badiou and the Subtraction from the State and the Community ${ }^{1}$
}

\author{
María J. López \\ University of Córdoba, Spain
}

Copyright (c) 2013 by María J. López. This text may be archived and redistributed both in electronic form and in hard copy, provided that the author and journal are properly cited and no fee is charged for access.

\begin{abstract}
The subtraction from forms of community and resistance to figures of authority that we find in Samuel Beckett's Trilogy can be approached in the light of Alain Badiou's critique of communitarian ethics and of the administrative and management function of the state, in which the individual is considered as a subset. It can also be seen as informed by the particular historical manifestations of political totalitarianism and authoritarianism that characterized the European context from which the Trilogy emerged. Drawing on Badiou's own readings of Beckett and on Andrew Gibson's revaluation of Badiou and Beckett, and as opposed to prevalent interpretations of the Trilogy that have underlined its despairing character and sole concern with the isolated ego, I would like to approach Molloy, Malone and the Unnamable as unconsenting and persistent individuals that refuse to become part of a community, reject established knowledges and resist to the conformity and obedience demanded by the state.
\end{abstract}

Key Words. Beckett, Trilogy, Badiou, Gibson, subtraction, resistance, state, community.

Resumen. En la Trilogía de Beckett, la sustracción de formas comunitarias y la resistencia a las figuras de la autoridad pueden ser analizadas a la luz de la crítica de Alain Badiou de la ética comunitaria y de la función de administración y gestión del estado, para la que el individuo es un mero subconjunto. También pueden verse como influenciadas por las manifestaciones históricas concretas del totalitarismo y el autoritarismo políticos que caracterizaban el contexto europeo del que surgió la Trilogía. Basándome en las lecturas de Beckett que el propio Badiou ha llevado a cabo y en el análisis de Beckett y Badiou realizado por Andrew Gibson, y en oposición a las interpretaciones imperantes de la Trilogía que han acentuado su carácter desesperado y su atención exclusiva al individuo aislado, me gustaría aproximarme a Molloy, Malone y el Innombrable como individuos rebeldes y tenaces que se niegan a formar parte de una comunidad, rechazan los conocimientos pre-establecidos y se resisten a la conformidad y obediencia exigidas por el estado.

Palabras clave. Beckett, Trilogía, Badiou, Gibson, sustracción, resistencia, estado, comunidad.

\section{Introduction}

According to Anthony Cronin, "the Beckett man belongs to no category, no class, no nationality or community" (2006: 88). This statement epitomizes an important current in the critical reception of Samuel Beckett that has emphasized the centrality in his works of the solipsistic and self-enclosed individual, and the absence - or deprecating undermining - of meaningful forms of collective affiliation. This critical tendency has generated a series of concepts and ideas

1. This article is part of a research project funded by the Spanish Ministry of Economy and Competitiveness (ref. FFI2012-36765), whose support is gratefully acknowledged. 
that have become commonplace in our reading of Beckett, such as the Cartesian split between mind and body; ${ }^{2}$ the isolated and alienated subject; ${ }^{3}$ or the impossibility of communication, mainly due to the barrier erected by language between ourselves and others. ${ }^{4}$ Beckettian characters are presented as alien to operative communities of any kind national, religious, political or ideological $-{ }^{5}$ something which cannot be seen as separate from what Cunningham (2008) has called the "abstraction" of Beckett's writings: the extremely oblique, ambiguous, formalized and scarce presence of social and historical references, if they appear at all. ${ }^{6}$

The protagonism of the isolated individual and the absence of the community are counterbalanced in Beckett's narrative and theatre by what we could call an intermediate social form, namely, the pair of characters or the couple: Gogo and Didi, Pozzo and Lucky, Winnie and Willie, Nagg and Nell, Hamm and Clov, Murphy and Celia, or Mercier and Camier. This has been seen as a device used to explore other issues and concerns. ${ }^{7}$ However,

2. See Kenner (1973) for his seminal Cartesian interpretation. Davies (1994) approaches Beckett's narrators as endowed with a Cartesian consciousness split off from the environment and its own organism.

3. This has to be seen as related to standard accounts of Anglo-Saxon modernism that have presented this movement as fundamentally concerned with the plight of an individual unable or unwilling to commune with an external reality. Thus, Lukács famously stated that in modernist literature, "man is by nature solitary, asocial, unable to enter into relationships with other human beings" (1963: 19), and Bradbury and McFarlane defined modernist art as an "art consequent on the disestablishing of communal reality" (1991: 27).

4. According to Davies, "from First Love to The Unnamable, all the narrators without exception have forgotten how to communicate" (1994: 54).

5. Again this has to be seen as related to a certain modernist ethos, in particular the fate or choice of exile, famously stated by Stephen Dedalus in $A$ Portrait of the Artist as Young Man, in his refusal to serve or to believe in "home," "fatherland," or "church" (Joyce 1992: 268-69).

6. Cunningham's point, however, is that we need to interrogate "the precisely historical and social meanings of such abstraction" (2008: 23). the most common critical tendency has been to identify in Beckett's engagement with the pair of lovers, friends or relatives a parodic or sardonic portrayal of love, friendship and family that undermines any high ideals we may associate with them and that points to the impossibility of going beyond our individual desires and needs, ${ }^{8}$ together with a reflection on the power, cruelty and potential suffering that haunts every human relationship. ${ }^{9}$

In any case, what the persistent presence of the pair of characters highlights is the impossibility of complete isolation and solipsism, the way the ego is always haunted by imaginary or real others, ${ }^{10}$ and the tension between individuality and collectivity. In the particular case of the The Trilogy, which constitutes the focus of this essay, the novels' main characters and narrators are haunted by certain others who seem to function as their doubles, with whom their identities end up merging, but whose existence is uncertain. Thus, in the second part of Molloy, the agent Jacques Moran sets out on the search for Molloy, whose story is traced in the first part, only to end up uncannily resembling him. Malone creates a character called MacMann, who seems to become Malone himself, and in The Unnamable, it is impossible to draw a line between the speaking voice and the stories he tells of Worm and Mahood.

7. Gilman argues that "in [Beckett's] theater relationships are never explored for their own sakes, not even as archetypes; what is explored is the nature of a reality where everything, including every relationship, is in doubt and tension" (1998: 237).

8. As put by Kiberd, the relationship between Murphy and Celia constitutes "Beckett's early warning that love between two people may be impossible, since each of us lives and dies alone" (2006: 41).

9. For Worton, "all of Beckett's pairs are bound in friendships that are essentially power-relationships" (1994: 71). Sheehan, in his insightful analysis of the necessary and gratuitous nature of suffering and cruelty in Beckett's work, points to how company tends to adopt the form of "the coupling of master and slave, interrogator and suspect or torturer and victim" (2008: 89).

10. As Brown (2011) analyzes from a psychoanalytic perspective, these others often do not assume the form of characters, but of voices. 
But I would like to go beyond the pair of characters and analyze the presence, however veiled and indeterminate, of a wider collectivity that assumes different forms along the Trilogy - the anonymous 'they' to whom Molloy hands in his texts, the organization to which Malone belongs, the asylum in which MacMann lives, or those whom the Unnamable calls his "delegates" (Beckett 1955: 297) and "tormentors" (347) - and to which the different narrators always resist. My argument is that the subtraction from forms of community and collective affiliation that we find in the Trilogy can be seen in the light of Alain Badiou's critique of communitarian ethics and his conception of the state of the historical-social situation as dealing with collective subsets and not with individuals (2007: 105). Following Andrew Gibson's response to Badiou and Beckett, and in particular his vision of The Unnamable as a text characterized by rage and the rejection of established ideas, I would like to explore the possibility that it is their refusal to become part of a community and their resistance to a state demanding conformity and obedience that leads Molloy, Malone and especially the Unnamable to become isolated egos. In their rejection of "circulating knowledge" (Badiou 2002: 50) and "communicative sociality" (Badiou 2002: 51), they are plunged into a solipsistic voice endowed with the qualities of resistance and perseverance.

\section{Beckett, Badiou and Gibson}

Alain Badiou's philosophy - which departs from a conception of being as an infinite multiplicity of differences ${ }^{11}$ and which uses mathematics as philosophical method - focuses on the idea of the event and the subject's fidelity to it. According to Badiou, the event implies a break with or radical innovation in an ordinary situation; as put by Hallward, "an event has no objective or verifiable content. Its 'happening' cannot be proved, only affirmed and proclaimed" (2002: ix). Truth, for Badiou, implies the subject's fidelity to the event, and this truth may take place in four domains: love,

11. Hence, Badiou's radical critique of the Levinasian ethics of the other - "infinite alterity is quite simply what there is" (2002: 25) - and his proposal of an ethics of truth and the Same (2002: 27-29, 40-57). art, science and politics. ${ }^{12}$

Badiou has extensively read and written on Beckett, following a long line of philosophers that have paid careful attention to the Irish writer. ${ }^{13}$ According to Badiou, there are two distinct phases in Beckett's writing and thought. Until 1960, with Texts for Nothing as culmination of this trend and How It Is as a transitional work, Beckett's works deal with "the confrontation that opposed the suffering cogito to the grey black of being" (2003a: 16), whereas in later texts, such as Enough or Ill Seen Ill Said, the surprising encounter with the Other fissures the solipsism of the cogito. Thus, "Beckett's evolution goes from a programme of the One ... to the pregnant theme of the Two, which opens out onto infinity" (2003a: 17).

Gibson structures the most comprehensive comparative study of Badiou and Beckett upon the concept of "the remainder": "the negligible historical residue" "to which events are counterposed and into which they break" (2006: 18). Whereas Badiou focuses on the event, banishing the remainder to the margins, the Beckettian world, according to Gibson, takes place in the remainder: the event may be recalled or evoked, but it "can scarcely be said to take place at all" (2006: 26). Gibson also disagrees with Badiou's linear interpretation of Beckett's production, since "Beckett's treatment of the event is arguably multifarious, heterogeneous, and uneven, and cannot be encapsulated in narrative form" (2006: 132).

It is on Gibson's reading of The Unnamable, as opposed to Badiou's, that I would like to focus. Both Badiou and Gibson depart from existentialist or nihilist interpretations of Beckett, but in the particular case of The Unnamable, Badiou "shares the common assumption that [it] is a tormented text"

12. In the first two chapters of his book on Badiou and Beckett, Gibson (2006) provides an excellent summary of Gibson's philosophical proposal.

13. For a general picture of the relation between Beckett and philosophy, see Moran (2006). For an overview of Badiou's response to Beckett in the context of the critical reception of the Irish writer in France, see Weller (2009). Joubert analyzes Badiou's critical revaluation of Beckett, arguing that in it, "the ethical pathos of nihilism is simply reversed into an equally pathetic repositivation of value, and a return to the staples of moralistic tradition" (2012: 42). 
(Gibson 2006: 187), in which Beckett "is playing a hopeless Cartesian game" (Gibson 2006: 186). ${ }^{14}$ Gibson, on the contrary, endows this work with a quality of rebelliousness that derives from the "rage against doxa" (2006: 188) traversing it. In his approach to Beckett, Gibson is actually following Badiou's proposal of an ethics of truth that is the complete opposite of an "ethics of communication" (Badiou 2002: 52), with opinion (or doxa) being precisely "the primary material of all communication" (2002: 51). For Badiou, "every truth ... deposes constituted knowledges, and thus opposes opinions. For what we call opinions are representations without truth" (2002: 50). Gibson, thus, places The Unnamable within "the tradition, inaugurated by The Republic, of texts whose first principle is the bracketting off of established ideas, the interrogation of the world as given" (2006: 188). The Unnamable carries out a "work of subtraction" in relation to the language imposed by those he calls 'tyrants', and especially in relation to their ideas and the world of opinion; hence, the "references to education, college, lectures, courses, and so on" (2006: 189).

I fully agree with Gibson's reading, but I would like to put the emphasis elsewhere, incorporating Molloy and Malone Dies, to which Gibson does not pay attention, into my analysis. In Logic of Worlds, Badiou asserts that "to the extent that it is the subject of a truth, a subject subtracts itself from every community" (2009: 9). This statement highlights Badiou's present position as one of the most outspoken enemies of communitarianism, since according to Badiou, the subject, in order to be faithful to the event, must subtract himself from the community. This is why Badiou presents Saint Paul - and his fidelity to the resurrection of Christ - as an exemplary figure: "Paul's unprecedented gesture consists in subtracting truth from the communitarian grasp, be it that of a people, a city, an empire, a territory, or a social class" (2003b: 5). Gibson compares Beckett's Unnamable with Badiou's Paul in the following sense: "Like the Unnamable, supremely in the Beckett canon, Badiou's Paul hears the logic of identity promoted by established knowledge as

14. See Badiou 2003a: 10-15. persecutory and oppressive" (2006: 73). My aim is to underline how for the Unnamable, and also for Molloy and Malone, the persecutory and oppressive character of established knowledge very much derives from its communitarian dimension, to which they most fiercely resist.

Blackman has called Beckett a "Resistant Writer" (2008: 71), drawing on Badiou's following meditation, in Metapolitics, on membership to the French Resistance:

No group, no class, no social configuration or mental objective was behind the Resistance. ... a Resistance figure 'by logic' obeys an axiom, or an injunction, which he formulates in his own name, and whose major consequences he lays out, without waiting to win over other people, in the objective group to which he belongs. Let us say that his resistance, proceeding by logic, is not an opinion. Rather it is a logical rupture with dominant and circulating opinions (2006: 5-6).

As it is well known, Beckett joined the French Resistance after the German occupation in 1940, working as a courier. The War and the Resistance are behind the continuous references along the Trilogy to physical pain, violence, authority or veiled and inaccessible meanings. According to Kenner, what we find in The Unnamable is "the Gestapo theme: the theme of the man who is required to talk, and in fact does not possess the information his tormentors must be made to think they have extracted" (1973: 109). ${ }^{15}$ As Gibson (2010: 109-127) has shown, the atmosphere of terror, suspicion and indifference to the suffering of others that reigned in France after the Liberation, with the series of purges carried out against former collaborationists with the Germans and the Vichy regime, also informs the Trilogy, which Beckett began writing in May 1947. What we find in these three novels, however, is not "direct evocation or historical representation" (Gibson 2010: 122), but oblique and displaced allusions: "history in the Trilogy exists as rubble, as debris strewn across its pages" (ibid.). My point is that Molloy's, Malone's and the Unnamable's suspicion towards forms of authority and resistance to collective or communal affiliation can be seen as informed by the particular historical manifestations of authoritarianism prevailing during Beckett's

15. For Kenner, the Trilogy, like Godot, is "an 'Occupation' book" (1973: 110). 
writing of the Trilogy.

Borrowing Badiou's words in the above quotation, Beckett's narrators are, to a certain extent, "Resistance figures" that do not belong to any social group; do not follow collective axioms or injunctions, but only those formulated in their own names; and break away from dominant opinions. They also resist inclusion and coercion by the state as defined by Badiou: "the essence of the State is that of not being obliged to recognize individuals when it is obliged to recognize them, in concrete cases, it is always according to a principle of counting which does not concern the individuals as such" (2007: 105). The state is always the state of the ruling class (Badiou 2007: 106), which we can see as represented by the different figures of authority and power that Molloy, Malone and the Unnamable encounter and that always have an "administrative or management function" (Badiou 2007: 106).

This does not imply, however, that the Trilogy's protagonists are subjects of truth or political activists in Badiou's sense. Politics, for Badiou, can be defined as "an assault against the State" (2007: 110), and it is certainly one of the domains in which the event may take place. When the subject maintains a resilient fidelity to the event, truth comes into being, a truth that is universal in its address (Hallward 2002: ix) and that implies a selfless devotion to a cause (Hallward 2002: xi). There are no recognizable events or truths in such terms in Beckett's Trilogy. If the event is a "supplement" that "cannot be reduced to its ordinary inscription in "what there is" and that "compels us to decide a new way of being" (Badiou 2002: 41), Beckett's characters are trapped in an endless existential tedium and meaninglessness from which no rupture seems possible: "But what matter whether I was born or not, have lived or not, am dead or merely dying, I shall go on doing as I have always done, not knowing what it is I do, nor who I am, nor where I am, nor if I am" (Beckett 1955: 226). On the other hand, the subject of truth, in his fidelity to truth, is "in excess of himself, because the uncertain course [tracé aléatoire] of fidelity passes through him, transfixes his singular body and inscribes him, from within time, in an instant of eternity" (Badiou 2002: 45). Beckett's characters, on the contrary, are most of the time unable to go beyond their own ego: "now there is no one here but me, no one wheels about me, no one comes towards me, no one has ever met anyone before my eyes, these creatures have never been, only I and this black void have ever been" (Beckett 1955: 304). This moment in The Unnamable resembles many others in which the narrating voice seems to acknowledge that there are and there have never been other voices, but only his.

In the light of Badiou's philosophical proposal, then, the Trilogy does not work in positive terms, but in terms of subtraction and resistance in relation to the state and the community. Also in terms of perseverance, a key element in Badiou's ethics, in which we find "the ethical maxim: 'Keep going!' [Continuer!]" (2002: 52), of which the ending of Beckett's The Unnamable constitutes a supreme example: "I can't go on, I'll go on" (Beckett 1955: 414). ${ }^{16}$

Slavoj Žižek quotes the Unnamable's last words arguing that "this simple persistence against all odds is ultimately the stuff ethics is made of" (2006: 120). Hallward argues that according to Badiou's philosophy, there is an 'ordinary' realm of established knowledges, and an 'exceptional' realm of "rare individuals", "militants" of their cause" (2002: viii). Molloy, Malone and the Unnamable are certainly 'rare individuals' that do not give up their cause: that of resisting the conformity and obedience demanded by the status quo and of going on in spite of the lack of certitude and hope.

\section{Molloy: "I had no papers"}

The Trilogy begins with an image of simultaneous subjection and resistance of the individual to a collectivity, one concerning the narrative itself. Molloy asserts that he is in his mother's room, where a man comes every week, gives him money and takes away the pages he writes: "What I'd like now is to speak of the things that are left, say my goodbyes, finish dying. They don't want that.... When he comes for the fresh pages he brings back the previous week's. They are marked with signs I don't understand. Anyway I don't read them" (Beckett 1955: 7). According to Kenner, it is not clear who wants his statements, why, or

16. For a discussion of the correspondence between Beckett's and Badiou's ethical maxims, see Gibson (2006: 97) and Hallward (2003: 265). 
why they are displeased with them, and identifies the "they" with "a kind of tolerant Gestapo" (1973: 92). The passage underlines not only the different codes of meaning inhabited by Molloy and 'they', but also Molloy's disrespectful stance toward them, as he does not even read their signs. The pronoun 'they' is repeated ad nauseam in the Trilogy, especially in The Unnamable. It cannot be endowed with a fixed and particular identity, but what is clear is the opposition between 'I' and 'they', who try to assimilate and incorporate the resisting 'I'.

In this sense, the 'they' very much functions like the state in Badiou's sense. As Hallward explains, Badiou uses the term 'state' in both its political and ontological senses simultaneously (2003: 96). Within the state, "the individual is considered as a subset" (Badiou 2007: 107), being subject to an "elementary coercion", which consists in "not being held to be someone who belongs to society, but as someone who is included within society" (ibid.). As put by Hallward, "the state ... is what discerns, names, classifies, and orders the part of a situation. In our national example, the state is of course what organizes the parts of its situation as legal residents, taxpayers, soldiers, social security recipients, criminals, licensed drivers, and so on" (2003: 96). Anyone familiarized with the Beckettian world will know that his characters not only those of the Trilogy -, in their cultural and physical homelessness (Davies 1994: 46), resist coercion by the state and inclusion within society.

We see this early in the Trilogy, when Molloy is stopped by a policeman as he is caught resting by his bicycle, "a violation of I don't know what, public order, public decency" (Beckett 1955: 20). $\mathrm{He}$ is asked to show his papers, but all he has are bits of newspaper to wipe himself with: "I had no papers in the sense this word had a sense for him, nor any occupation, nor any domicile, ... my surname escaped me for the moment" (22). The policeman is representative of a state that maintains order by keeping elements "in their proper, established places in the situation" (Hallward 2003: 96). The identity documents that Molloy is asked to provide would be the material proof of his being a subset of the state. However, as he has no job, home or even surname, he evades the state's task of classification and organization. He does not belong to any group or class of individuals.
Still, and this is the paradoxical state in which all characters in the Trilogy find themselves, in spite of his evasion of the state's coercion, Molloy is, at least partly, subjected to those he calls "his superiors" and whom he blames for behaving like a pig, as they did not show to him "the essence of the system, after the manner of the great English schools, and the guiding principles of good manners" (Beckett 1955: 25). Again, what is shown is Molloy's inability to follow social norms and collective conventions. When a group of people appears in the Trilogy, usually in the form of the crowd, they are always presented in negative terms, as bearers of what Badiou calls a "consensual ethics, which tries to avoid divisions" (2002: 75), as when Molloy runs over Louise's dog and describes the jeering crowd as "all these righteous ones, these guardians of the peace" (Beckett 1955: 34). Or when he leaves Louise's house and wandering across his region, feels again menaced by an anonymous 'they': "They wake up, hale and hearty, their tongues hanging out for order, beauty and justice" (Beckett 1955: 67). The sardonic and contemptuous reference to universally accepted values such as 'peace', 'order', 'beauty' and 'justice', and the way the community or collectivity is presented as defendant of those values, highlights that if there is an ethical proposal in the Trilogy, it is one close to Badiou's ethics, an ethics that dictates the fidelity to a truth process that "is heterogeneous to the instituted knowledges of the situation. Or - to use an expression of Lacan's - that ... punches a 'hole [trouée]' in these knowledges" (2002: 43). As pointed out in the previous section, it is improbable that there is a truth process to which Beckett's characters are faithful, but they certainly punch a hole in instituted knowledges. Badiou is inspired by Lacan's command "do not give up on your desire" (2002: 47), according to which being faithful to your desire requires "the repudiation of all consensual social norms (happiness, pleasure, health, etc.) in favour of an essentially asocial, essentially traumatic exception" (Hallward 2003: 265), again terms that can be applied to Beckett's characters' experience. In the second part of Molloy, however, we come across an individual that fully complies with consensual social norms and accepts his position as a subset within the 
state, materialized in the organization to which he belongs. He is Jacques Moran, the agent that, through the messenger Gaber, is assigned the mission of looking for Molloy and writing a report. The order apparently comes down from Youdi, "a mysterious linguistic and metaphysical authority" (Saunders 2011: 59). At the beginning of the narrative, Jacques Moran seems to be Molloy's opposite. If, as we have seen, Molloy belongs to no community and is external to the state, Moran is a bourgeois and religious citizen. As opposed to Molloy's vagrant character, the first picture we get of Moran is a domestic one: when he receives the order to see about Molloy, he is in his little garden, waiting to go to church, surrounded by the smoke coming from his neighbours' chimneys. If Molloy is a victim of the authorities, Moran is an agent of authority. Whereas Molloy is constantly afraid of being interrogated, Moran, as figure of power, is interrogator of his son (Beckett 1955: 108, 117), on whom he violently imposes a lifestyle of discipline in which indolence and play are banned.

However, Moran turns out to be no master, but servant, "faithful servant", feeling "hatred in [his] heart, and scorn, of [his] master and his designs" (132). He is in deep fear of Youdi and the punishment he may get if he does not comply with his orders (162), and in fact when Gaber finds him - after wandering around, having lost his son, his bicycle and his money and having begun to experience a physical disintegration that very much resembles Molloy's - he is most anxious to know whether Youdi is angry (164). Moran, then, substantially differs from the other narrators of the Trilogy, Molloy, Malone and the Unnamable: although these three do not totally escape power relationships, they do resist them and are not fully coerced by the state, as in Moran's case. He can be seen as an example of the destructive effects that the domination and repression of the state may have on the consenting man.

\section{Malone Dies: "Let me go!"}

Malone, lying on a bed in a room, with an exercise-book and a pencil as his main possessions, tells us the story of Macmann, which we suspect may be his own story. What especially interests us is Macmann's stay in the asylum, which, together with its clear
Foucauldian echoes, ${ }^{17}$ can be approached from Badiou's critique of the state and the community. This is the welcome Macmann receives in the institution, in which he suddenly finds himself: "They said in substance, You are now in the House of Saint John of God, with the number one hundred and sixty-six. Fear nothing, you are among friends. Friends! Well well. Take no thought for anything, it is we shall think and act for you, from now forward" (256). This particular situation is exemplary of Badiou's idea, as explained by Hallward, that "in an ordinary situation, the domination of its state is effectively absolute ... It is precisely this indetermination that ensures conformity or obedience from (classified, divided ...) members of the situation" (2002: ix). Macmann's status in the asylum as a subset, and not an individual, is highlighted by the fact that he is just a number. The aim of the collective 'we' in charge of the institution is that of subsuming the individual, thinking and acting for him, and thus depriving him of autonomy and agency, which is probably the reason why Macmann "had eluded charity all his days" (Beckett 1955: 256), just like Molloy, who argues that "against the charitable gesture there is no defence" (24).

When he is asked to sign a paper, "Macmann had obeyed, either because he was afraid of being punished if he refused or because he did not realize the seriousness of what he was doing" (256). As in other passages in the Trilogy, the fear of punishment suggests the individual's subjection to a structure of power and intimidation, whereas the act of writing like Molloy's narrative or Moran's report - also takes place within a structure of coercion. Similar to other figures of authority that we encounter along the Trilogy, the asylum's keepers are in charge of individuals, subjecting them to continuous vigilance and control, as we see in the particular case of Moll, Macmann's keeper: "She informed Macmann, when he did something, if that thing was permitted or not, and similarly, when he remained inert, whether or not he was entitled to" (257).

But Macmann ends up rebelling against this disciplinary regime. His first act of rebellious-

17. See Uhlmann (1999) for a thorough analysis of Beckett in the light of Foucault and other poststructuralist thinkers. 
ness takes place after Moll's death, who is substituted by Lemuel: "May I get up? he said one day. Already in Moll's life he has expressed the wish to get up and go out into the fresh air, but timidly, as when one asks for the moon" (267). Lemuel starts, then, to hit himself with a hammer, to which Macmann's response increases in intensity: "Up! cried Macmann. Let me up! Lemuel came to a standstill. What? he roared. Up! cried Macmann. Let me up! Let me up!" (269). The scene stops here, but later in the narrative, we see Macmann abandoning his cell and going outdoors, "deaf to the call of the bell and to the shouts and threats first of Lemuel, then of the other keepers" (275). On Easter weekend, Lemuel assembles five asylum inmates to take them to a picnic on an island, and again Macmann's attitude is one of resistance: "Of the five it was Macmann, furious at having been shut up in his cell all morning and at a loss to understand what was wanted of him, whose resistance had been the most lively" (283-284). The "dichotomy between surrender and control" (1988: 194) that Connor identifies in the Trilogy is present in Macmann's predicament. On the one hand, he is subjected to the institution and to Lemuel. On the other hand, he resists such subjection, as he does not stop saying: "Let me go! Let me go!" (Beckett 1955: 284).

Connor analyzes the struggle for control in narrative terms (1988: 194). This dimension is certainly present but my point is that in line with the rest of the Trilogy, the subjection and resistance - to an oppressive collectivity also works in socio-historical terms. After killing two sailors with his hatchet, Lemuel sets out into the sea with his inmates, including Macmann: "Lemuel is in charge" (Beckett 1955: 288). However, Macmann asserts, "he will not hit anyone any more" (ibid.). Lemuel's position of power, then, is uncertain. The important point, in any case, is that the contest between the institution he represents and the individual Macmann has been staged.

\section{The Unnamable: "I'm not their creature"}

The Unnamable's struggle is the struggle to resist being incorporated into 'they':

How they must hate me! Ah a nice state they have me in, but still I'm not their creature, not quite, not yet. ... Not to be able to open my mouth without proclaiming them, and our fellowship, that's what they imagine they'll have me reduced to. It's a poor trick that consists in ramming a set of words down your gullet on the principle that you can't bring them up without being branded as belonging to their breed (324)

As this passage highlights, 'they' hate the Unnamable because he resists becoming 'their creature' and proclaiming their 'fellowship', that is, becoming part of their collectivity. His refusal to be 'branded as belonging to their breed' is characterized by the "vocabulary of plenitude, or of substance" (Badiou 2002: 72) that Badiou condemns in "the absolute particularity of a community, itself rooted in the characteristics of its soil, its blood, and its race" (2002: 73), and brings echoes of the totalitarian regimes and identitarian politics that characterized the historico-political context from which the Trilogy emerged, as explained above. They are bent on making him part of the community - "what they were most determined for me to swallow was my fellowcreatures" (Beckett 1955: 298) - but the Unnamable refuses to yield.

He calls them "delegates" (297), "gentlemen" (ibid.) and "agents" (298), figures that - like policemen in Murphy or asylum's keepers in Malone Dies - evoke the world of bureaucracy and authority, the world of the state, that Beckett's vagrant, homeless characters constantly bump into. And they "disturbers of my peace" (299), "a whole college of tyrants" (310), "the beleaguerers" (392), "tormentors" and "devils" (347) certainly exert power and coercion over the Unnamable, especially as they try, as argued by Gibson (2006: 189), ${ }^{18}$ to stuff him with their ideas:

The things they have told me! About me, the light of day. I refused to believe them. I remember little or nothing of these lectures. ... They gave me courses on love, on intelligence, most precious, most precious. They also taught me to count, and even to reason. Some of this rubbish has come in handy on occasions. ... I use it still, to scratch my arse with (297-98).

18. As put by Connor, "knowledge and culture are seen unequivocally as the exercise of power" (1988: 194-195). 
The 'lectures' and 'courses' the Unnamable has received highlight the circulation of opinions, "the anarchic debris of circulating knowledge" (Badiou 2002: 50). But just as for Badiou, "established knowledges" (Badiou 2002: 75) are devoid of truth, for the Unnamable, they are just 'rubbish'. He has received a discursive education to which he is expected to respond with discursive obedience: "it is in fact required of me that I say something, something that is not to be found in all I have said up to now" (Beckett 1955: 311). But he refuses to believe what he has been taught, resisting consensus.

The, the Unnamable's struggle is also the struggle to find his own voice, discarding inherited, collective, authoritarian voices: "Ah if I could only find a voice of my own, in all this babble" (348). However, as Gibson has pointed out, "it is not possible simply to step outside or have done with the realm of opinion" (2006: 99). The Unnamable is actually aware of the fact that he has "no words but the words of others" (Beckett 1955: 314); that he must speak of himself "with their language" (324); that he has "no language but theirs" (325); all in all, that he has no voice or ideas of his own: "these voices are not mine, nor these thoughts, but the voices and thoughts of the devils who beset me" (347). Thus, he inhabits the paradox of being trapped in his solipsistic voice, at the same time that he resists "communicative sociality" (Badiou 2002: 51).

In relation to The Unnamable, Badiou has written "on the solipsistic subject as torture" (2003a: 10). My point is that the torture of speaking of himself and for himself is somehow chosen by the Unnamable in order to escape another torture, the torture of having to speak for his master: "Speak, yes, but to me, I have never spoken enough to me, never listened enough to me, never replied enough to me, never had pity enough on me, I have spoken for my master, listened for the words of my master" (Beckett 1955: 310). He is given the choice of joining them and their language, but chooses banishment instead:

Do they consider me so plastered with their rubbish that I can never extricate myself, never make a gesture but their cast must come to life? But within, motionless, I can live, and utter me, for no ears but my own. ... Can it be they have abandoned me, saying, Very well, there's nothing to be done with him, let's leave it at that, he's not dangerous. Ah but the little murmur of unconsenting man, to murmur what it is their humanity stifles, the little gasp of the condemned to life, rotting in his dungeon garrotted and racked, to gasp what it is to have to celebrate banishment, beware (325).

In spite of the value he gives to the refusal to consent, Badiou does not recognize this quality in the Unnamable, who can actually be seen as an example of 'unconsenting man': "Do they think they'll lull me, with all this hemming and hawing?" (Beckett 1955: 347). ${ }^{19}$ The Unnamable will not let himself be trapped or appeased by the soothing, stupefying effect of their language, of their opinions and established knowledges. That is why I fully agree with Gibson's contention that "The Unnamable ends on a victorious note", which "has seldom if ever been suggested" (2006: 195). The Unnamable's - at least, partial victory lies in the fact that he will go on being faithful to his choice of banishment, to "the traumatic, irreducible, essentially asocial and asymbolic particularity of [his]" - and not their - "experience" (Hallward 2002: xvii).

Badiou wonders in his Ethics: "What would become of us, miserable creatures, if all this did not circulate and recur among the animals of the City? To what depressing silence would we condemn ourselves? Opinion is the primary material of all communication" (2002: 51). Badiou refers to "the weather; the latest film; children's diseases; poor salaries; the government's villainy; the performance of the local football team; television; holidays ..." (2002: 50) as examples of opinion, precisely the kind of references we do not find in the novel that closes the Trilogy, in which language tends more and more towards what Badiou has called "the generic": "the reduction of the complexity of experience to as few principal functions", namely, "going, being, and saying" (2003a: 3). Without opinions, we would condemn ourselves to the 'depressing silence' of the Unnamable's unceasing voice; we would be condemned to lack of communication and of sociality; we would become the 'miserable creature' that the

19. As pointed out by Gibson, "for both Badiou and Beckett, this quite distinctively radical refusal to consent is where the labour for both freedom and justice begins" (2006: 193). 
Unnamable is. Language would just become a 'murmur' and a 'gasp'. But beware. That murmur may say more about humanity than all our 'courses' and 'lectures'.

\section{Works Cited}

Badiou, Alain. 2002. Ethics: An Essay on the Understanding of Evil. Trans. Peter Hallward. London: Verso. 2003a. On Beckett. Ed. Nina Power and Alberto Toscano. Manchester: Clinamen Press. 2003b. Saint Paul: The Foundation of Universalism. Trans. Ray Brassier. Stanford: Stanford UP. 2006. Metapolitics. Trans. Jason Barker. London: Verso. 2007. Being and Event. Trad. Oliver Feltham. London: Continuum.

2009. Logic of Worlds: Being and Event, 2. Trans. Alberto Toscano. London and New York: Continuum

Beckett, Samuel. 1955. Three Novels: Molloy, Malone Dies, The Unnamable. New York: Grove Press.

Blackman, Jackie. 2008. "Post-war Beckett: Resistance, Commitment or Communist Krap?". Beckett and Ethics. Ed. Russell Smith. London: Continuum. 68-85.

Bradbury, Malcolm and James McFarlane (eds.). 1991. Modernism: A Guide to European Literature 1890-1930. London: Penguin.

Brown, Llewellyn. 2011. "Voice and Pronouns in Samuel Beckett's The Unnamable", Journal of Beckett Studies 20.2. $172-196$.

Connor, Steven. 1988. Samuel Beckett: Repetition, Theory, and Text. Oxford: Basil Blackwell.

Cronin, Anthony. 2006. "Beckett's Trilogy". In Samuel Beckett: 100 Years: Centenary Essays. Ed. Christopher Murray. Dublin: New Island. 88-92.

Cunningham, David. 2008. “'We have our being in justice': Formalism, Abstraction and Beckett's 'Ethics"'. In Beckett and Ethics. Ed. Russell Smith. London and New York: Continuum. 21-37.

Davies, Paul. 1994. "Three Novels and Four Nouvelles: Giving Up the Ghost Be Born at Last". In The Cambridge Companion to Beckett. Ed. John Pilling. Cambridge: Cambridge University Press. 43-66.

Gibson, Andrew. 2006. Beckett and Badiou: The Pathos of Intermittency. Oxford: Oxford UP. 2010. Samuel Beckett. London: Reaktion Books.

Gilman, Richard. 1998. "The Stage: Beckett's Happy Days". In The Critical Response to Samuel Beckett. Ed. Catheleen Culotta Andonian. Westport, Connecticut: Greenwood Press. 235-237.

Hallward, Peter. 2002. "Translator's Introduction". Ethics: An Essay on the Understanding of Evil, Alain Badiou. London: Verso. vii-li.

2003. Badiou: A Subject to Truth. Minneapolis: University of Minnesota Press.

Joubert, Claire. 2012. "Badiou with Beckett: Concept, Prose and the Poetics 'd'avenir". Journal of Beckett Studies 21.1. 33-55.

Joyce, James. 1992 (1914). A Portrait of the Artist as a Young Man. London: Penguin.

Kenner, Hugh. 1973. A Reader's Guide to Samuel Beckett. London: Thames and Hudson.

Kiberd, Declan. 2006. "Murphy and the World of Samuel Beckett". In Samuel Beckett: 100 Years: Centenary Essays. Ed. Christopher Murray. Dublin: New Island. 34-47.

Lukács, Georg. 1963. The Meaning of Contemporary Realism. London: Merlin Press.

Moran, Dermot. 2006. "Beckett and Philosophy". In Samuel Beckett: 100 Years: Centenary Essays. Ed. Christopher Murray. Dublin: New Island. 93-110.

Saunders, Paul. 2011. "Samuel Beckett's Trilogy and the Ecology of Negation". Journal of Beckett Studies 20.1. 54-77.

Sheehan, Paul. 2008. "A World Without Monsters: Beckett and the Ethics of Cruelty". In Beckett and Ethics. Ed. Russell Smith. London and New York: Continuum. 86-101.

Uhlmann, Anthony. 1999. Beckett and Poststructuralism. Cambridge: Cambridge University Press.

Weller, Shane. 2009. "Beckett among the Philosophes: The Critical Reception of Samuel Beckett in France". In The International Reception of Samuel Beckett. Ed. Mark Nixon and Matthew Feldman. London: Continuum. 24-39. 
Worton, Michael. 1994. "Waiting for Godot and Endgame: Theatre as Text". In The Cambridge Companion to Beckett. Ed. John Pilling. Cambridge: Cambridge University Press. 67-87.

Žižek, Slavoj. 2006. How to Read Lacan. London: Granta Books.

Received $7^{\text {th }}$ November 2012. Last version $22^{\text {nd }}$ January 2013.

María J. López is a lecturer in the English Department at the University of Córdoba, Spain. She has published Acts of Visitation: The Narrative of J.M. Coetzee (Rodopi, 2012) and has published in journals such as the Journal of Southern African Studies and the Journal of Commonwealth Literature. She has written on writers such as Patrick White, Salman Rushdie, Anita Desai, Zoë Wicomb and Virginia Woolf. Her current research interests focus on forms of community in British modernism and contemporary South African literature, and on the (anti)pastoral tradition in the South African novel in English. 